\title{
Consumer Behavior in "Groupon" Business in Vietnam
}

\author{
HÀ NAM KHÁNH GIAO \\ Associate Professor, Doctor of Philosophy, University of Finance and Marketing \\ Email: khanhgiaohn@yahoo.com \\ NGUYẼ̃N HOÀI PHƯONG \\ Master of Business Administration, San Ha Technique JSC \\ Email: goldenchance@gmail.com
}

\begin{abstract}
This research aims to identify the factors that influence online shopping behavior of consumers in "Groupon" business in Vietnam. The results provide information to determine the importance level of each selected factors and find out the most important factor among these proposed factors. Multiple Linear Regression and One-Way ANOVA method are used. The results indicate three factors that have impacts on online shopping in Groupon business: Perceived benefit in Price, Trust and Convenience. The research results also point out there are no differences in attitude toward online shopping in Groupon business between gender, education and age group.
\end{abstract}

Keywords: Groupon, e-commerce, online business, consumer behavior, online shopping. 


\section{INTRODUCTION}

During the past decade, consumers around the world are turning to the Internet for their shopping needs and concerns. According the research of Miniwatts Marketing Group, about two billion people worldwide have been using the Internet. As many researchers indicated, more Internet usage results in more potential online purchases. Recently, there have been many stories about the success of doing business on Internet such as Google.com, Facebook.com, Twitter.com, Ebay.com, and Amazon.com, etc.

During the economic crisis in 2008-2009, a seminal business model in e-commerce sector was introduced in the USA on a deal-of-the-day website named "Groupon.com". Consumers sign up a deal in the website with high discount rate $(30 \%-90 \%)$. If a certain number of people register to buy a deal on the website, then that deal becomes available to them; if the number of sold vouchers does not reach the predetermined number as commitment between a merchant and a website owner, no one has the deal that day. This business model reduces risk for retailers who can use the coupons as quantity discounts as well as sales promotion tools. "Groupon" site makes money by getting a share of the deal from the retailers. The idea of this e-commerce website and its business model is quite simple but brings about big successes. Known as a project in which the firm's value reaches one billion dollars in sales faster than any other business until now, this business model attracts huge investments and has developed very fast in many countries.

With minimal barriers to entry, "Groupon" business was copied and applied all over the world. From the middle of the year 2010, several similar websites were built in Vietnam, for example, cungmua.com, nhommua.com, doimua.com, and muachung.vn, etc. Until the present research finished in August 2011, there were more than 50 cloned "Groupon" sites. In Vietnam, the "Groupon" business model has its own advantages such as competitive prices, new product information channel for consumers, advertising channel for small and medium companies, shops or restaurants. It is clear that many competitors appeared nearly at the same time in Vietnam. As a result, the market is much more competitive when the companies start their business as "Groupon" model.

\section{LITERATURE REVIEW}

According to MORI (2001), the level of e-shopping is related much to Internet accessibility. Consumers who are not able to access the Internet can hardly be e- 
shoppers. Brengman et al. (2005) believe that Internet usage is a decisive factor in recognition of online consumers; therefore, they are segmented through recognition of Internet-usage style. In addition, e-shopping awareness is another factor that influences e-shopping. Consumers who are well aware of advantages of Internet and have high level of Internet use are really potential e-shoppers.

Engel et al. (2001) pointed out that social influence plays an important role in affecting consumers' online purchasing decisions. Social-cultural influences come from family, friends, age group, and culture. Websites can serve as social tools enabling consumers to set up connections. In addition, online communities enable consumers to socialize and interact further facilitating the exchange of information.

Price is clearly the important factor in both online and offline shopping, especially in the case where selling price is much lower than usual. Customers consider the price of product to be higher or lower in comparison with the internal standards (Dodd et al. 1991). This also implies that the perceived product price affects consumer's choice and evaluation rather than actual price.

After comparing traditional shopping with online one, Monsuwé et al. (2004) found that online shopping is a more convenient way of shopping. From the Internet, lots of product/service information can be gathered for consumer consideration with little effort, inconvenience, and required time. Monsuwé et al. (2004) concluded that convenience factor is really relevant to the identification of online consumers.

Consumers' trust in online shopping and prior experience with online shopping were identified as having a significant impact on consumers' intention to do eshopping. Smith and Rupp (2003) found that trust, security, and prior experiences are important factors to e-shoppers.

Smith and Rupp (2003) found some factors influencing online buying behavior. This process comprises three stages: (1) Operational input, (2) Process, and (3) Output. In the first stage, the consumer is influenced by the marketing efforts made by the media and the socio-cultural influences. For the process stage, it identifies and explains how the consumer makes the buying decision online. We divided the factors into two groups: (1) factors related to consumer: Internet usage and e-shopping awareness, demographics, attitude and belief, personal characteristics, and psychological characteristics; and (2) factors related to the website: Web experience, price of product/ service, convenience of online shopping, and trust in online shopping. In this 
stage, price, convenience and trust are main determinants for the consumer's intention to shop online. The last stage is identified as the output stage, which is a post-purchase decision process. By examining various studies the author has identified certain factors that were constantly present in the literature. Hence, a conceptual framework was developed (Figure 1) from the aforementioned discussion.

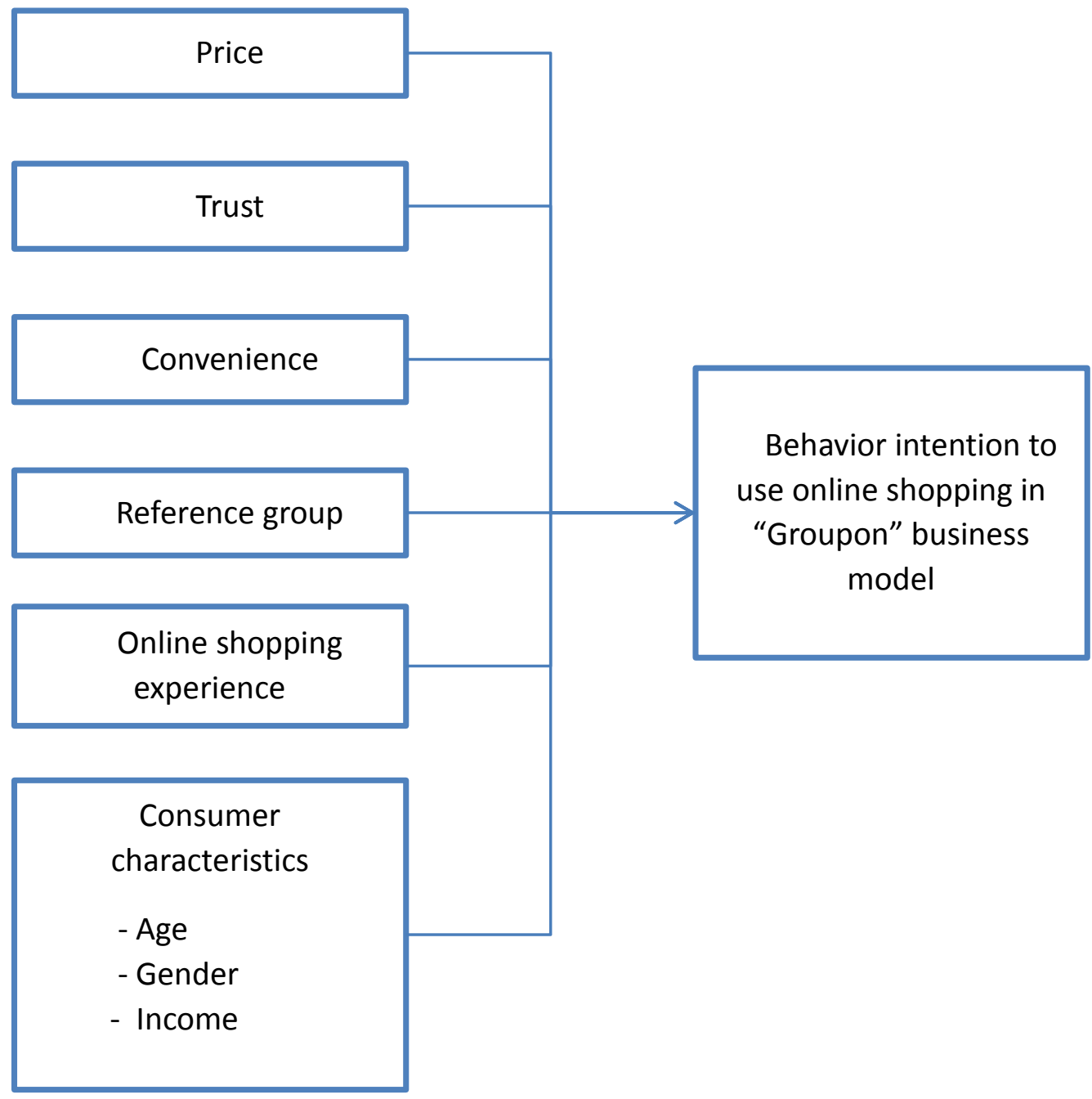

Figure 1: Conceptual Framework

Source: Adapted from consumer decision-making model for online shopping behavior, Smith and Rupp, 2003 


\section{METHODOLOGY}

This research was conducted by deductive approach. Firstly the theory is presented from general to specific levels, then questionnaires are distributed and collected primary data are analyzed. Frequency distribution of the respondents was carried out according to questions related to demographic and webographics attributes. Multiple regressions and analysis of variance (ANOVA) were conducted. Multiple regression method is used to estimate the unknown value of variables - also called as the predictors, including: Online Shopping Experience, Reference Group, Price, Trust, and Convenience factors. ANOVA method is used to find any differences in attitude toward online shopping intention between groups of Age, Education, and Gender. The analysis enables us to examine the individual relationship between the independent variables and attitude toward shopping in "Groupon" business.

\section{RESULT AND DATA ANALYSIS}

Due to the purpose of this research, only the questionnaire method is suitable to the topic and able to collect the answers in a satisfactory manner. Questionnaire for consumer survey was processed in two steps. Firstly, 10 friends who have knowledge of the Groupon were interviewed directly for the purpose of understanding the testing survey. Secondly, questionnaire was adjusted and issued officially. The survey was carried out on Google Docs tool and interviewees were invited by email, then the collected raw data would be analyzed by SPSS. The survey collected 209 valid responses out of total 221 respondents' answers, 12 responses were rejected because the respondents did not complete the questionnaires. The demographics of respondents are presented in Table 1 .

Table 1: Analysis of Demographic Factors by Using Frequency and Percentage

\begin{tabular}{lccc}
\hline & Demographics & Frequency & Percentage \\
\hline \multirow{2}{*}{ Gender } & Male & 81 & 44.3 \\
& Female & 102 & 55.7 \\
\hline \multirow{2}{*}{ Age } & $16-22$ & 13 & 7.1 \\
& $23-28$ & 114 & 62.3 \\
& $29-34$ & 47 & 25.7 \\
& $>35$ & 9 & 4.9 \\
\hline
\end{tabular}




\begin{tabular}{llcc}
\hline Education & High school or lower & 15 & 8.2 \\
Colleges & 5 & 2.7 \\
Bachelor degree & 153 & 83.6 \\
& Master or higher & 10 & 5.5 \\
\hline
\end{tabular}

The reliability of a measure indicates the stability and consistency with which the instrument measures the concept. All constructs were tested for the consistency and reliability of the items within the constructs by using the Cronbach's alpha reliability analysis. About the reliability test results in Table 2, Cronbach's alpha of over 0.6 and all corrected item-total correlations of over 0.3 are required for all factors in the research (Hair et al. 1998). Cronbach's alpha for the constructs ranged from the lowest of 0.621 to 0.784 . The results showed that the Cronbach's alpha for all the constructs used in this research exceeded the preferable scores of 0.60 and this indicated that the measurement scales of the constructs were stable and consistent.

Factor analysis confirmed that the construct validity measurement, which was adopted in this research, could be performed adequately (Cavana et al. 2001). Table 2 presents the detail results of this analysis. From the output, the value of Kaiser-MeyerOlkin (0.684) was above the recommended level of 0.5 (between 0.5 and 1.0), implying the factor analysis was appropriate. The statistical test for Bartlett's test of sphericity was significant $(\mathrm{p}=0.000)$ for all the correlations among selected variable within a correlation matrix. Based on the principal components analysis and the most popular procedure in orthogonal rotation (VARIMAX), the output also implied that the Eigen criteria values for all the factors were more than 1.0. As the result of convergent validity, the factor loadings for all items in the research were greater than 0.6. Discriminant validity pointed out that all constructs were completely different from each other. In consequence, the items were not overlapping, and the respective constructs were supported. 
Table 2: Factors Identified by the Principal Components Factor Analysis

\begin{tabular}{|c|c|c|c|c|c|}
\hline $\begin{array}{c}\text { Factor's } \\
\text { Name }\end{array}$ & Variable & $\begin{array}{l}\text { Factor } \\
\text { loading }\end{array}$ & Eigenvalue & $\begin{array}{c}\text { Percentage } \\
\text { of } \\
\text { Variance } \\
\text { Explained }\end{array}$ & $\begin{array}{l}\text { Cronbach's } \\
\text { Reliability } \\
\text { Coefficients }\end{array}$ \\
\hline Trust & $\begin{array}{l}\text { My private information is } \\
\text { protected. } \\
\text { Voucher delivery is on time. } \\
\text { Trading transaction is } \\
\text { correct. } \\
\text { Quick response to my } \\
\text { question or complaint. } \\
\text { Quality of product is the } \\
\text { same as description in the } \\
\text { website. }\end{array}$ & $\begin{array}{l}0.786 \\
0.777 \\
0.729 \\
0.708 \\
0.634\end{array}$ & 2.922 & 19.481 & 0.784 \\
\hline Convenience & $\begin{array}{l}\text { I find it easy to look for and } \\
\text { compare product } \\
\text { information. } \\
\text { I can purchase from the } \\
\text { "Groupon" websites anytime } \\
\text { in day. } \\
\text { I find it less strained when } \\
\text { purchasing in "Groupon" } \\
\text { model compared to other } \\
\text { places. }\end{array}$ & $\begin{array}{l}0.838 \\
0.790\end{array}$ & 2.430 & 16.168 & 0.712 \\
\hline $\begin{array}{c}\text { Online } \\
\text { shopping } \\
\text { experience }\end{array}$ & $\begin{array}{l}\text { I have experience in online } \\
\text { shopping. } \\
\text { My previous experience in } \\
\text { online shopping in } \\
\text { "Groupon" business model } \\
\text { has gone well. }\end{array}$ & $\begin{array}{l}0.858 \\
0.840\end{array}$ & 1.810 & 12.064 & 0.718 \\
\hline $\begin{array}{l}\text { Reference } \\
\text { group }\end{array}$ & $\begin{array}{l}\text { My friends influence my } \\
\text { intention in shopping in } \\
\text { "Groupon" business model. }\end{array}$ & 0.810 & 1.407 & 9.382 & 0.621 \\
\hline
\end{tabular}




\begin{tabular}{l|l|l|l|l|l}
\hline & $\begin{array}{l}\text { My relatives influence my } \\
\text { intention in shopping in } \\
\text { "Groupon" business model. }\end{array}$ & 0.795 & & & \\
\hline & $\begin{array}{l}\text { Online discussions in group } \\
\text { or forums influence my } \\
\text { intention in shopping in } \\
\text { "Groupon" business model. }\end{array}$ & 0.635 & & & \\
\hline Price & $\begin{array}{l}\text { I find it important to save } \\
\text { money in shopping. }\end{array}$ & 0.838 & & 8.359 & 0.622 \\
\hline
\end{tabular}

Note: KMO Measure of Sampling Adequacy =0.684; $\mathrm{p}=0.000(\mathrm{p}<0.05) ; \mathrm{df}=105$.

Cumulative Percentage Rotation Sums of Squared Loadings $=65.485$

Table 3 shows the result of regression analysis, the "Benefit in price" impacts positively on consumer purchase intention in "Groupon" business model, as p value $(.001)$ is less than 0.05 . "Trust" ( sig. $=.000)$ and "Convenience" (sig. $=.000)$ are also significant predictors.

Table 3: Coefficient of Multiple Linear Regression Model for Attitude towards Online Shopping in "Groupon" Business

Coefficients

\begin{tabular}{|c|c|c|c|c|c|c|c|c|}
\hline \multirow{2}{*}{ Model } & \multicolumn{2}{|c|}{$\begin{array}{l}\text { Unstandardized } \\
\text { coefficients }\end{array}$} & \multirow{2}{*}{$\frac{\begin{array}{c}\text { Standardized } \\
\text { coefficients }\end{array}}{\beta}$} & \multirow{2}{*}{$\mathbf{t}$} & \multirow{2}{*}{ Sig. } & \multicolumn{3}{|c|}{ Correlations } \\
\hline & B & $\begin{array}{c}\text { Std. } \\
\text { Error }\end{array}$ & & & & $\begin{array}{l}\text { Zero- } \\
\text { order }\end{array}$ & Partial & Part \\
\hline 1 (Constant) & $-4.318 \mathrm{E}-16$ & .067 & & .000 & 1.000 & & & \\
\hline Trust & .262 & .067 & .262 & 3.903 & .000 & .262 & .282 & .262 \\
\hline Convenience & .252 & .067 & .252 & 3.751 & .000 & .252 & .271 & .252 \\
\hline Online shopping experience & .040 & .067 & .040 & .589 & .556 & .040 & .044 & .040 \\
\hline Reference group & .127 & .067 & .127 & 1.900 & .059 & .127 & .141 & .127 \\
\hline Price & .233 & .067 & .233 & 3.467 & .001 & .233 & .252 & .233 \\
\hline
\end{tabular}

a. Dependent variable: Purchase intention 
We also find that $\mathrm{R}=45.1 \% ; \mathrm{R}^{2}=20.4 \%$; and adjusted $\mathrm{R}^{2}=18.1 \%$, implying the factors can explain $18.1 \%$ of the meaning of the dependent variable; $\mathrm{F}=9.058 ; \mathrm{P}=$ $0.000(p<0.05)$. Based on the result of SPSS output, the estimated regression equation is written as follows:

Customer Online Purchase Intention in "Groupon" Business $=0.262 *($ Trust $)+$ $0.252 *($ Convenience $)+0.04 *($ Online Shopping Experience $)+0.127 *($ Reference Group) $+0.233 *$ (Price)

Therefore "Trust" is the most important antecedent that affects customer's online purchase intention. "Convenience" and benefit in "Price" factors have the second and third position in the list of important antecedents affecting the customer's online purchase intention in "Groupon" business model. In addition, the customer's online purchase intention can be explained up to $18.1 \%$ (adjusted $\mathrm{R}^{2}$ ) by the combination of various independent variables, which includes trust orientation, convenience orientation and price orientation.

Regarding the output from SPSS for ANOVA test, the result shows that there are no differences in attitude toward online shopping in Groupon business between gender, education and age group.

\section{DISCUSSION}

From the results of the multiple regression analysis, only three out of five factors have significant impacts on attitude toward shopping in "Groupon" business model. They are "Trust", "Convenience" and benefit in "Price" factor. Consumers may be attracted by high discount in price at first purchase, and in order to keep them returning back, other factors should be added. The analytical results are generally consistent with previous studies. Trust is one of most important factors (Koufaris and Hampton-Sosa, 2004) in forming positive consumer attitude toward online shopping, and from the study results, it has received the most consistent support as factors that influence consumer attitude towards shopping in "Groupon" business model. Marketers need to realize that the online marketing environment affects the way consumers view and develop relationships. In this context, trust is everything they need to add value to the online shopping experience and to build relationships.

The second most important factor is "Convenience" which is similar to the past studies by other authors (Constantinides, 2004). A practical assessment of these dimensions revealed that individuals who purchase online, perceive value convenience 
as one of the most significant advantages of online shopping. Therefore, online retailers need to ensure that the online shopping process through their websites is made as simple and inexpensive as possible for consumers to shop online.

The research also clearly indicates that prices are the third important factor affecting consumers' purchase intention. The result is consistent with the findings of previous researches. Therefore, in order to attract online shoppers to their websites and encourage them to make a purchase decision, "Groupon" sites need to provide products and services of competitive price. However, this may lead to intense price competition which is anticipated to rise even more with the availability of powerful search engines and comparing shopping websites that enable consumers to easily compare services and product offerings from various "Groupon" sites.

This research also shows that online shopping experience factor has no direct and significant effect on intention to do online shopping in "Groupon" model. This result contradicts those of previous studies done by other researchers. This contradicting result might be due to the fact that the purchase transaction in this mode of business is quite simple. Consumers only need to supply some simple information such as name, location and phone number when they sign up a deal for confirmation afterward.

Contrary to previous researches, the reference group is found to produce no impact on consumer behavior. The lifespan of each deal is short and consumers might make purchase decision by themselves without being influenced by other people.

Moreover, the Internet and online shopping is more and more popular with residents in big cities, people of different ages and education levels, especially for the simple, interactive and visual websites like the one of "Groupon" business model. The company need not develop different marketing strategies for different gender, age and education level groups in context of Vietnamese consumers. That will definitely result in great saving not only in terms of their operation cost but in the overall planning of the strategy.

\section{CONCLUSION AND IMPLICATION}

The research was conducted using a theoretical framework based on existing literature. In the past, there were many researches on online shopping or e-commerce in Vietnam. The present research, however, is one of the first studies of "Groupon" business. This study proposed a model that represents important determinants of a consumer's intention in an online shopping at "Groupon" sites. This study enhances 
the current body of knowledge on e-commerce, specifically our understanding of consumer behavior in "Groupon" business model. It is hoped that the paper will stimulate further scholarly discussion on consumer behavior in other kinds of ecommerce sites. This study investigates factors affecting online users' attitudes toward "Groupon" site; how those factors affect consumer intention to use online shopping in "Groupon" model; and what is the most important factor; and finally offers recommendations about the research model.

The multiple regression analysis shows that trust, convenience and price are significant factors affecting intention of consumer in online purchase of "Groupon" business model. Trust is the most important factor in this study and is also very crucial to competition among business organizations in today's global business world. Convenience is the second most important factor that causes positive effects on buying decision of consumer. In the research business model, the price of product or service is always lower by $30 \%$ to $90 \%$ compared to normal price in the market. That attracts people to buy, and as a result pricing is also the third factor that has significant impact on attitude of consumer toward online shopping of "Groupon" business model.

This research is particularly helpful for managers of the "Groupon" sites who have yet to convert non-loyal to loyal consumers. Understanding consumers' perception on online shopping of "Groupon" model is not an easy task and will always create challenges to most online e-commerce sites. Those managers should develop effective plans and strategies by taking into account various factors that were explained in this study

\section{References}

Brengman, M., M. Geuenes, B. Weijters, M.S. Smith, \& R.W. Swinyard (2005), "Segmenting Internet Shoppers Based in Their Web-Usage-Related Lifestyle: Across Cultural Validation", Journal of Business Research, 58, 79-88.

Cavana, R., B.L. Delahye, \& U. Sekaran (2001), Applied Business Research: Qualitative and Quantitative Methods. Wiley, Milton, Australia.

Constantinides, A. (2004), "Influencing the Online Consumer's Behavior: The Web Experience", Internet Research, 14(2), 111-126.

Dodds, W. B., K.B. Monroe, \& D. Grewal (1991), "Effects of Price, Brand, and Store Information on Buyers Product Evaluation”, Journal of Marketing Research, 28(3), 307-319. 
Engel J.F., R.D. Blackwell, \& P.W. Miniard (2001), Consumer Behavior, The Dryden Press Series in Marketing.

Hair, J.F., R.E. Anderson, R.L. Tatham \& W.C. Black (1998), “Multivariate Data Analysis”, New Jersey: Prentice-Hall International, Inc.

Koufaris, M. \& W. Hampton-Sosa (2004), "The Development of Initial Trust in an Online Company by New Customers", Information and Management, 413, 377-397.

Monsuwé, P.T., C.G.B. Dellaert \& K. Ruyter (2004), "What Drives Consumers to Shop Online? A Literature Review", International Journal of Service Industry Management, 15(1), 102-121.

Mori, S. (2001), Informing Customers About E-shopping: Qualitative Survey Report.

Smith, Alan D. \& William T. Rupp (2003), "Strategic Online Customer Decision Making: Leveraging the Transformational Power of the Internet", Journal of Emerald Group, 27(6), 418432. 